"The EUrASEANs: journal on global socio-economic dynamics"

Volume 2 (21); March-April, Year 2020;

ISSN 2539 - 5645 (Print)

Copyright (C) 2019, [The EUrASEANs]

on-line access: https://www.euraseans.com/2(21)

\title{
URBAN CREATIVE CLUSTERS AS A FACTOR OF GLOBAL ECONOMIC EFFICIENCY
}

\author{
Tatiana Podolskaya \\ Aleksey Baranov \\ Ludmila Tomashevskaya \\ Russian Presidential Academy of Economy and Public Administration (RANEPA), \\ Rostov-on-Don, Russia
}

In the paper the authors analyze theoretical approaches to definition and classification of creative clusters, including used by the international economic organizations. The role and influence of creative economy for modern development of the urbanized cities is shown. In the paper the production factor which is basic for creation of added value in creative economy is designated. The authors show influence of the creative industries on development of world economy using of relevant analytical materials and statistical data. On the basis of the retrospective analysis from the Russian and foreign practice experience of creation and development of the creative cities is analyzed. Such mechanisms of change of the urbanized cities' public space as a placemaking and redevelopment are described. In the study the

\section{Tatiana Podolskaya}

Candidate of Economic Sciences, Associate Professor, Head of Department of International Economic RelationsatSouth Russian Institute of management of Russian Presidential Academy of Economy and Public Administration (RANEPA). The area of scientific interests includes issues of trends of modern world economy, role of transnational corporation, international financial system, as well as the problems of its regulation. Tatiana Podolskaya is the author of more than 90 scientific papers, 5 textbooks, 3 monographs.

E-mail: tv.kuraeva@mail.ru

\section{Alexey Baranov}

Senior Lecturer of the Department of Management RANEPA, Deputy Director of the Institute. Alexey Baranov the author of more than 20 publications, educational, teaching and methodical supplies. The area of scientific interests includes the problems of commercialization and technology transfer in Russia, the creation and management of small innovative enterprises, administrative reform, e-government.

E-mail:meo@uriu.ranepa.ru

\section{Ludmila Tomashevskaya}

Candidate of Philological Sciences, Associate Professor of Department of Foreign Languages. The areas of scientific interest include Language Theory (Lexicology, Semasiology). She has over 45 years of teaching experience at Rostov-on-Don Teachers Training Institute, Russian Customs Academy and Russian Presidential Academy of National Economy and Public Administration. She has written various language programs and resource books for pre-work students of Foreign Languages Department, Customs Administration Department and Economy Department. She has been teaching General English, Business English, English for Professional Purposes and delivering elective courses in Intercultural Management and Organizational Management.

E-mail: meo@uriu.ranepa.ru 
comparative analysis of creative economy's key indicators of the world capitals - leaders in development of the creative environment in dynamics is carried out. Analysis is based on the data of the Global Creativity Index and the interrelation of creativity level with urban saturation and competitiveness of the countries and cities.

Keywords: creative clusters; urbanized cities; creative economy; the UNESCO Creative Cities Network; classification of creative industries; the Global Creativity Index; the Global Competitive Index; the Human Development Index; the Creative Capital Index

\section{The Role of Creative Clusters in the Development of Urbanized Cities}

One of the key indicators determining the quality of life in a modern urbanized city is the level of cultural development. Cultural environment often determines the positioning of a city, its social and tourist attractiveness. Large, highly urbanized cities, on the territories of which corporate management units operate, can guarantee there will be sufficient demand for creative clusters. Moreover, they already have sufficient infrastructure and popular travel brands to attract more tourists as consumers of creative goods and services.

Dynamically developing processes of automation and robotization are having their impact on national economies worldwide, primarily through releasing a significant number of industrial workers from their routine jobs, thus making it possible for them to shift to more creative work. In the foreseeable future, creative clusters will consequently become the growth drivers for many national economies globalwide. The "Experience Economy" concept developed by B. J. Pine and D. H. Gilmort (1999) is used sometimes interchangeably with the term "knowledge economy". Within this concept, there is a significant range of products, which are aimed at influencing the emotional sphere of the individual, not only in terms of goods and services consumption, but also in terms of personal development and selfrealization.

In this context, development of creative clusters is not just emergence of a new sector of the economy. It will entail fundamental structural changes and, provided there is a consistent government strategy supporting it on a specific territory, it will become a key factor of economic growth. A separate session on export potential of the creative sectors became one of the central discussions at the St. Petersburg International Economic Forum (SPIEF) in summer 2018. Opening this session at SPIEF-2018, Andrey Slepnev, Director General of the Russian Export Center, noted that "it is very important to understand the role of intelligence in the future economy".

The leading expert participants highlighted the undoubted role of creative industries as an instrument of "soft power". Forming national images should be a priority and go hand in hand with the development of creative clusters in urbanized centers and territories. "The images created today by our animation and film industry can form a solid basis for creating a new positive image of Russia, which offers not only energy resources, but also something good and useful for children and adults alike", said Andrey Slepnev (Galkina, 2018).

At the international level, establishing creative clusters in urban economies is perceived as a driving force for sustainable development, the basis for innovations' implementation in the framework of the second resolution, adopted by the UN General Assembly on September 25, 2015 "The transformation of our world: the sustainable development agenda for the period up to 2030" and on 23 December 2016 "New Urban Development Program". 
Although the term "creative industries" appeared in the mid-twentieth century it became known to the general public relatively recently - in the early 21 st century already. Below we present our own overview of approaches to defining the terminology associated with the development of creative clusters.

\section{Classification of Industries Attributed to Creative Economy}

The World Intellectual Property Organization (WIPO) classifies areas of activity as being creative by means of copyright (this classification is presented in Table 1).

Table 1 - Classification of creative industries protected by copyright, developed by the World Intellectual Property Organization

\begin{tabular}{|c|c|c|}
\hline Copyright-Based Industries & Related industries & Partly copyrighted industries \\
\hline - advertising; & - copying materials; & - architecture; \\
- collecting; & - consumer electronics; & -clothes and shoes \\
- film and video; & - musical instruments; & manufacturing; \\
- music; & - paper; & - fesign; \\
- performing arts; & - copying and photo equipment. & -household goods and toys \\
- publishing; & & \\
- software; & & \\
- television and radio; & & \\
- visual and graphic arts. & & \\
\hline
\end{tabular}

Table 2 - Comparison of approaches to definition of creative/cultural industries in the selected of countries around the world

(Source: Analytical materials, 2016)

\begin{tabular}{|l|c|c|c|c|c|}
\hline & UK & Germany & Spain & Singapore & France \\
\cline { 2 - 5 } & $\begin{array}{c}\text { Creative } \\
\text { industries }\end{array}$ & $\begin{array}{c}\text { Cultural and } \\
\text { creative } \\
\text { industries }\end{array}$ & $\begin{array}{c}\text { Cultural } \\
\text { industries }\end{array}$ & $\begin{array}{c}\text { Creative } \\
\text { industries }\end{array}$ & $\begin{array}{c}\text { Cultural } \\
\text { sector }\end{array}$ \\
\hline Architecture & + & + & + & + & + \\
\hline $\begin{array}{l}\text { Audio and video } \\
\text { technologies (films, } \\
\text { radio, television) }\end{array}$ & + & + & + & + & + \\
\hline Performing art & + & + & + & + & + \\
\hline Libraries & + & + & + & + & + \\
\hline Design & + & + & + & + & + \\
\hline Visual arts & + & + & + & + & + \\
\hline Publishing & + & + & + & + & + \\
\hline Fashion & + & + & + & + & + \\
\hline Software / Multimedia & + & + & + & + \\
\hline $\begin{array}{l}\text { Museums / Cultural } \\
\text { Heritage }\end{array}$ & + & + & + & + & + \\
\hline Music & + & + & + & + \\
\hline Crafts & + & + & + & + \\
\hline Advertising & + & + & + & + \\
\hline
\end{tabular}


Trying to take into account the specifics of their national economies, different countries attribute various spheres to their creative sectors. Tab. 2 shows a comparison of the most widely used classification of creative and cultural industries.

An independent approach to classification of creative industries was developed by Calvert Forum which positions itself as a think tank supporting creative and cultural industries. Table 3 presents industries classified as creative ones within the framework of the generalized classification of this international project (Analytical materials, 2014).

Variety of the presented classifications indicates that creative clusters are developing very dynamically while techniques for recording the results of their activities are still in their infancy. This makes cross-country comparisons and analyzing creative clusters activities in a single state or territory significantly complicated and calls for the need to harmonize approaches to assessing the composition of creative clusters' elements.

Table 3 - Classification of creative industries by Calvert Forum

(Source: Analytical materials, 2016)

\begin{tabular}{|c|c|c|c|}
\hline Arts and culture: & Design: & $\begin{array}{c}\text { Media and } \\
\text { communications: }\end{array}$ & Digital technology: \\
\hline $\begin{array}{l}\text { - photography; } \\
\text { - visual arts; } \\
\text { - performing arts; } \\
\text { - arts and antiques; } \\
\text { - crafts; } \\
\text { - literature; } \\
\text { - libraries; } \\
\text { - museums / galleries / } \\
\text { archives; } \\
\text { - cultural heritage; } \\
\text { - auctions; } \\
\text { - festivals and cultural } \\
\text { initiatives. }\end{array}$ & $\begin{array}{l}\text { - advertising; } \\
\text { - architecture; } \\
\text { - interior design; } \\
\text { - graphic design; } \\
\text { - industrial design; } \\
\text { - fashion; } \\
\text { - communication design; } \\
\text { - environment design; } \\
\text { - jewelry production. }\end{array}$ & $\begin{array}{l}\text { - publishing; } \\
\text { - television and radio; } \\
\text { - advertising; } \\
\text { - films and videos; } \\
\text { - sound recording; } \\
\text { - mass media; } \\
\text { - public relations. }\end{array}$ & $\begin{array}{l}\text { - website design and } \\
\text { development; } \\
\text { - software design and } \\
\text { engineering; } \\
\text { - computer } \\
\text { programming; } \\
\text { - application design; } \\
\text { - IT strategies and } \\
\text { planning. }\end{array}$ \\
\hline
\end{tabular}

\section{Experience in Building Creative Cities}

Creative cities appeal to young people who are naturally drawn to everything new, are willing to take risks and aspire to change the system of values and lifestyle. The high-risk nature of creative activity does not only fail to discourage young people but, on the contrary, stimulates their activity. Therefore, it is the youth that is the key driver of creative economy. Most countries have been developing creative economies through provision of favorable conditions for creative young people, first and foremost, by establishing creative business environment in the form of creative spaces. Thus, some principal forms of creative spaces organization have emerged in the world economy during the last couple of decades, creative city being one of them.

Creative cities aim to shape the local innovative environment, with the products and services made there to be introduced primarily in that very city agglomeration. It is a modern-day paradox that with almost unlimited Internet access and ever-increasing number of virtual offices, almost all major technology companies still tend to concentrate in compact urban mega centers such as London, Berlin, San Francisco, Helsinki and others.

The "creative city" concept originated in the UK. It was there that creative economy 
was first recognized as a priority objective for government policy. The 1980s' economic crisis brought about the need to work out specific guidelines for developing creative industries. The spin off was attracting new investment and significantly increasing employment opportunities. Thus, the process of establishing creative clusters in abandoned industrial estates took off.

Regional and local governments were given much wider responsibilities to deal with major issues arising while developing creative cities. To effectively implement government policy in this area an integrative approach was applied, covering rent reduction and other small business support projects (soft loans, counselling etc.).

Berlin is considered to be a major international creative center. According to Berlin City Hall Report of 2015 (Creative Industries in Berlin. Development and Potential), 7245 creative sector enterprises were operating in the city, such as artists' neighborhoods, centers of modern arts, theatre and concert venues, various art clusters and objects (Third Creative Industries Report, 2015).

Another good example of a creative city is Essen, where in the 1930s a fourteensquare-mile Zollverein complex of mines was built. The mines were closed down during the 1980s' economic crisis. In 1988, the local government of North Rhine-Westphalia approved a scheme to transform the industrial estate into a center for design, education, tourism and culture. The former mine premises now house: the Museum of the Ruhr area and the Museum of Modern Industrial Design, the Design Center of North Rhine-Westphalia, the Center for Contemporary Choreography art studios and offices of creative companies. The Zollverein Center annually attracts about 800,000 tourists and modern artists.

On the opposite side of the planet, in China, Shanghai and Beijing are probably the most known examples of creative cities.

In Beijing, an electronics factory was built in the 1950s by the architects from thenGDR - the largest project of East Germany in China. Today it is the world famous center of Chinese avant-garde art, hosting artists' workshops, exhibition halls and theatres. Factory 798 is one of the most popular tourist attractions in the capital of China.

Shanghai achieved the status of the national creative center through gradual step-bystep actions by the government. It is there that the annual International League of creative industries has been held since 2004.

In Russia, the trends described above are notable in Moscow at such active projects as Flakon, Art play, Fabrika, ARMA, Winery. Some other Russian cities have also established successful creative cities by changing the format of urban public spaces. The examples are New Holland in St. Petersburg, Industrial and Creative Cluster Octava in Tula, Headquarters of Creative Industries in Kazan, Center of Contemporary Arts in Cheboksary and others. These projects show that creative industries are open to any kind of contacts, their workers tend to think out of the box, they are willing to transform cognitive styles, change the very system of consumption, reimagine and reinvent public space.

"Creative city" is a rather broad concept which describes city as a component of international or national creative economy. In fact, the cities described above have only some special zones engaged in creative activities. Such zones are also referred to as "creative quarters." These functional creative components of urban public space draw the creative class, tourists and the local community.

One of the popular forms of public urban space transformation is placemaking. This innovative community-driven bottom-up approach to area development was introduced in 
Russia in the 21st century. The most notable example of domestic placemaking is the 2014 reconstruction of several Moscow streets: Pyatnitskaya, Pokrovka and Maroseyka, where the pedestrian zones were considerably increased, bicycle lanes were created, modern street lamps and comfortable, beautiful benches were installed, facades and signs were repaired. Today the streets are popular destinations for both tourists and the Muscovites.

Another current trend in upgrading urban environment is the reconstruction of park complexes and embankments in order to make them cost-effective. Despite the difficulty of assessing the impact of public space on urban economy, as rightly noted by Alexander Puzanov, the director of the Foundation for the Institute of Urban Economy, its modernization results in significant indirect economic effects, such as increased well-being of people, who actively visit well-maintained and inviting parks, social capital development and the reduction of people's outflow from such cities as well as creation of new jobs, tourist destinations and convenient venues for public cultural events. Commercializing public spaces is widespread in the US. Zuccotti Park on a privately owned public space in New York, the Millenium Park in Chicago are just a few examples of such successful projects.

International experience shows that nations with the most developed creative economies are often focused on establishing creative spaces for their active expanding creative class. Creating a comfortable environment to stimulate creative entrepreneurial activity results in significant synergy effect for all the accompanying sectors.

This means encouraging young people's creativity, fighting/preventing the outflow of talented youth from the country, improving people's well-being and developing national economy overall. Not all those engaged in creative industries manage to succeed, actually. Many startups have failed to develop to the stage of becoming an actual business. However, innovative projects that have been implemented considerably changed the existing markets for goods and services acting as the drivers of national economy. Accordingly, the principal task of regulatory authorities in this field would be establishing innovative spaces with creative atmosphere, as well as providing conditions for commercialization of the results creative cluster workers produce.

\section{Assessment of Creativity in the World Capitals, Leading in Creative Clusters' Development}

The described above 3 "T" concept (talent, technology, tolerance) developed by Richard Florida (2005) was criticized by a number of authors because the parameters of its indices were defined by the limited number of indicators. In particular, it was noted that the 3 "T" concept indicators refer mainly to science and innovations and have little relevance to evaluating the impact of culture and creativity (Landry, 2011).

While acknowledging the need to include the 3 "T" factors in the new models of creativity, the researchers also highlighted the need to take into account some other key indicators for enhancing the creativity of the city, such as urban environment, government's position regarding creative sector, city dwellers' cultural and social engagement as well as opportunities for creative potential realization.

In view of the growing significance of creativity for economic development in urban centers, Calvert 22 Foundation and $\mathrm{PwC}$ Russia started to develop the Creative Capital Index, a benchmarking research project to reveal the key economic factors that make for innovative cities. The objective for developing this index is stated as "benchmarking the 
potential of the top dynamically growing cities regarding their prospects for economic modernization and investment attractiveness" (Creative Capital Index, 2017). It is strange that although creativity is recognized as the key driver for economic growth and increasing efficiency, there is no reference to it either in the objective for developing the index, or in its practical application.

Explaining the need for the introduction of the "creative capital" category, experts point out to the limitations of "human capital" and "innovative potential" concepts regarding their ability to explain the prerequisites for establishing creative environment and building successful post-industrial economy. Meanwhile, the idea of the modern urban center, accumulating creative capital, suggests there is direct interdependence between the quality of urban services and the arrival of highly qualified creative workers into the city (Creative Capital Index, 2017).

Terry Clark, professor of Columbia University, in his book "The city as an entertainment machine," emphasizes the interrelation and interdependence between highly developed cultural sector and entrepreneurial projects' concentration which are essential for achieving dynamic and effective development in the urbanized centers.

The findings in the research evaluating creative economy in the world capitals, leading in creative environment during 2012-2015 (see Tab.4 for details) suggest that Moscow had one of the top spots when it comes to the dynamics of creative sector development. This is primarily due to the fact that at the beginning of the period under analysis creative industries in Moscow had low ratings.

Yet, on the scale of creative economy Moscow was the next to last city, followed only by Hong Kong. Although the rates of creative sector are growing contribution to the gross regional product (GRP) in Moscow significantly exceeded those in other mega cities, being second only to Berlin. With the overall annual growth of Moscow economy of $12 \%$, the creative sector in the capital increased by $22 \%$.

The subsectors that brought about such rapid growth were Digital Technologies $(+41 \%$ annually), Design and Architecture ( $+20 \%$ annually), Arts and Culture ( $+14 \%$ annually). And this was, actually, in contrast to the simultaneous reduction in the employment rate in these sectors caused by the 2014 crisis. In particular, Design and Architecture sector and Arts and Culture sector saw the number of personnel decrease by $5 \%$, the IT sector - by $10 \%$, and the media sector - by as much as $22 \%$, all during 2010-2015. Notably, the growth rates in the Media sector were below the average for the overall urban economy, amounting to $7 \%$ only.

Table 5- Indicators of creative economy of the world capitals - leaders in the development of creative environment, 2012 to 2015

(Sources: Creative Capital in Global Cities, 2018)

\begin{tabular}{|c|c|c|c|c|c|c|c|c|}
\hline & 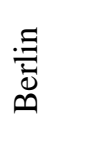 & 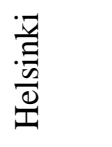 & 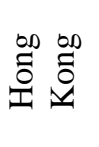 & 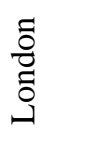 & $\begin{array}{l}3 \\
0 \\
0 \\
0 \\
\Sigma \\
\Sigma\end{array}$ & 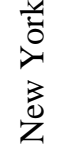 & $\bar{\Xi}$ & 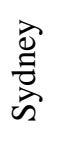 \\
\hline Volume of creative economy, in \% & 9.95 & 7.32 & 4.93 & 10.63 & 5.66 & 8.91 & 7.42 & 8.89 \\
\hline $\begin{array}{l}\text { Dynamics of the creative economy } \\
\text { development, in \% }\end{array}$ & 17.7 & -12.31 & -4.08 & 4.59 & 35.97 & 2.51 & -2.89 & -5.09 \\
\hline
\end{tabular}

Another indicator on which Moscow leads during this period was the growth rate of 
gross value added in the Digital Technology sector, which was 3.3 times higher than the GDP growth of Russian capital in 2010-2015 and it amounted to $+207 \%$ (Creative Capital in Global Cities, 2018).

The period under analysis was difficult for developing creative industries in urbanized centers. Half of the analyzed capitals showed some negative dynamics in the creative sector: the anti-leader is Helsinki (-12.31\%), Sydney, Hong Kong and Seoul also demonstrated negative results. Meanwhile, Helsinki leads on the urban environment and creative infrastructure development and is one of the global leaders in disclosure and use of public data by the government. Every year it spends about $17 \mathrm{mln}$ EUR on urban art and culture development.

London, Berlin and New York became the capitals leading in creative sector development during the analyzed period. Over the past five years the creative sector growth in London exceeded the overall growth of the metropolis economy by 5\% and amounted to $8 \%$. The most intensive growth was observed in the sectors of architecture ( $+22 \%$ annually), advertising and marketing $(+20 \%)$, as well as in the sectors of the so-called "cultural economy".

This segment accounts for $12 \%$ of the creative sector in London, while for other global creative capitals its figure ranges from $4 \%$ to $8 \%$. Meanwhile, "cultural economy" is experiencing one of the highest growth rates among all creative industries: the "Handicraft" segment grew by $17.5 \%$, and the sectors of music, visual and performing arts -- by $11 \%$. Given that London was among the first urbanized centers to develop a strategy to support creative and cultural industries in the early 1980s, and is actually a trendsetter in the field, it is natural to assume that the abovementioned areas of "cultural economy" will act as the defining factors for growth in other creative sectors of mega cities as well.

A modern urbanized center can be viewed as a complex system in which society, business and government must successfully coexist and solve city's problems, working against the background of the already existing infrastructure. The indicators defining the index of cities' creative capital can be loosely divided into objective and subjective ones. The sources for objective indicators are official statistics from international economic organizations and national statistical agencies. If information on the key indicators was missing in the statistical bodies of all levels, independent tools were applied, for example, geolocation services. Data on the subjective indicators come from sociological research, a survey of more than 100 creativity experts and an analysis of media references to cities in the context of creative industries. The indicators were converted into a universal value, employing statistical methods, adjusted for population size and urbanized area, and standardized ones, using cities' maximum values for each indicator.

All the indicators are combined into five main sections - People, City, Government, Business and Brands. They are presented in Table 6 with the assessment of eight world capitals, ranking highest in terms of creative environment development.

Table 6 presents some interesting information for analysis. Two capitals - London and New York - are ranked 2nd and 3d on "Research and education infrastructure" in the "City" section, yet they do not make the top four on "Education level" in "People" section, with New York scoring the lowest on this indicator. Surprisingly, "Creative New York" report, produced by the Center for Urban Future in 2015 states that Big Apple has more people engaged in creative industries than such creative centers as San Francisco and Los Angeles (Creative New York, 2015), with 9\% creative workers in America being New York residents. 
New York also takes the top spot in "Private entrepreneurial initiatives" in the "People" section, with 22 small and medium-sized businesses per 1,000 people living in the city.

Table 6 - Creative capital index of the world capitals - leaders in the development of creative environment in 2018

(Sources: Creative Capital in Global Cities, 2018)

\begin{tabular}{|c|c|c|c|c|c|c|c|c|}
\hline & 节 & 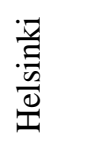 & 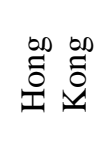 & $\begin{array}{l}\bar{\delta} \\
\bar{\sigma} \\
. \\
\end{array}$ & $\begin{array}{l}3 \\
0 \\
0 \\
\& \\
\Sigma\end{array}$ & $\begin{array}{l}\text { ü } \\
\grave{z} \\
z \\
z \\
z\end{array}$ & $\begin{array}{l}\bar{O} \\
\dot{D} \\
\tilde{n}\end{array}$ & 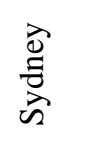 \\
\hline \multicolumn{9}{|l|}{ City } \\
\hline Economic ranking & 0.78 & 0.75 & 0.75 & 0.69 & 0.54 & 0.76 & 0.73 & $0.85^{*}$ \\
\hline Cultural life & 0.82 & 0.89 & 0.49 & 0.76 & 0.71 & 0.81 & 0.62 & 0.6 \\
\hline Urban environment & 0.81 & 0.83 & 0.54 & 0.81 & 0.41 & 0.75 & 0.59 & 0.66 \\
\hline Research and development infrastructure & 0.57 & 0.47 & 0.53 & 0.7 & 0.34 & 0.52 & 0.58 & 0.79 \\
\hline Average score for City section & 0.74 & 0.73 & 0.58 & 0.74 & 0.5 & 0.71 & 0.63 & 0.73 \\
\hline \multicolumn{9}{|l|}{ People } \\
\hline Education level & 0.67 & 0.54 & 0.61 & 0.57 & 0.61 & 0.39 & 0.66 & 0.54 \\
\hline Cultural engagement & 0.48 & 0.46 & 0.56 & 0.62 & 0.74 & 0.68 & 0.42 & 0.63 \\
\hline Private entrepreneurial initiative & 0.44 & 0.42 & 0.26 & 0.61 & 0.19 & 0.93 & 0.17 & 0.33 \\
\hline Creativity & 0.64 & 0.6 & 0.36 & 0.56 & 0.31 & 0.5 & 0.31 & 0.48 \\
\hline Openness and tolerance & 0.68 & 0.8 & 0.65 & 0.6 & 0.46 & 0.74 & 0.41 & 0.74 \\
\hline Average score for People section & 0.58 & 0.57 & 0.49 & 0.59 & 0.46 & 0.65 & 0.4 & 0.55 \\
\hline \multicolumn{9}{|l|}{ Business } \\
\hline Innovation and creative infrastructure & 0.43 & 0.8 & 0.16 & 0.22 & 0.33 & 0.25 & 0.16 & 0.16 \\
\hline Creative companies and projects & 0.52 & 0.8 & 0.1 & 0.42 & 0.28 & 0.31 & 0.23 & 0.06 \\
\hline Scale of creative economy & 0.85 & 0.25 & 0.33 & 0.67 & 0.55 & 0.34 & 0.41 & 0.42 \\
\hline Business environment & 0.45 & 0.4 & 0.38 & 0.72 & 0.49 & 0.55 & 0.32 & 0.24 \\
\hline Average score for Business section & 0.64 & 0.63 & 0.32 & 0.61 & 0.5 & 0.53 & 0.37 & 0.36 \\
\hline \multicolumn{9}{|l|}{ Government } \\
\hline Openness of government & 0.77 & 0.7 & 0.68 & 0.78 & 0.55 & 1.0 & 0.77 & 0.74 \\
\hline Support for business & 0.81 & 0.58 & 0.67 & 0.87 & 0.41 & 0.86 & 0.69 & 0.83 \\
\hline Average score for Government section & 0.79 & 0.64 & 0.68 & 0.82 & 0.48 & 0.93 & 0.73 & 0.79 \\
\hline \multicolumn{9}{|l|}{ Brands } \\
\hline Creative brands & 0.73 & 0.64 & 0.6 & 0.83 & 0.52 & 0.89 & 0.6 & 0.63 \\
\hline City image & 0.81 & 0.67 & 0.61 & 0.78 & 0.51 & 0.84 & 0.62 & 0.65 \\
\hline Cultural offer & 0.85 & 0.69 & 0.62 & 0.89 & 0.68 & 0.91 & 0.64 & 0.7 \\
\hline Average score for Brands section & 0.79 & 0.67 & 0.61 & 0.83 & 0.57 & 0.88 & 0.62 & 0.66 \\
\hline Index $* *$ & 69.78 & 64.73 & 53.29 & 70.48 & 49.62 & 72.32 & 54.13 & 61.94 \\
\hline
\end{tabular}

* highlights the results that are the maximum for the corresponding indicator for the analyzed period

** The adjusted values, except for the final index values are obtained by multiplying the initial figures for each section - on the scale from 0 to 1 - by 100 for greater clarity. The main sections of the index are included into the final index values with individual weightings

As for London, which ceased to implement an open migration policy and thus curbed the inflow on unskilled migrants, in contrast to Berlin (the leader on this indicator), the relatively low score on "Education level" is alarming. It is a weak rating for the global center where innovations in education used to be the key national strategy stimulating growth in creative industries. Meanwhile, universities in London offer the most diverse selection of 
educational programs on the subject of creative industries.

Among the benchmarked capitals, Moscow scores the lowest on "Research and education infrastructure" in the "City" section and shares 3-4 places with Hong Kong on "Education level" in the "People" section. This fact indicates that the level of education of the city dwellers remains high, although Moscow lags behind other capitals when it comes to infrastructure for research and education services.

Sydney had the first place on "Economic ranking" in the "City" section, it also took the top spot in research and educational environment: it leads in the number of students enrolled at universities of the TOP-500 of the "THE" rating, and the average number of programs in creative courses per university.

Notably, special content was developed for the indicators in the five main sections in order to determine the Creative Capital Index of 15 Russian cities. For example, the Creative Capital Index for Russian cities does not take into account "Cultural engagement" in "People" section, although Moscow scores the highest among the top eight world capitals on creative sector development. This leadership is supported by high availability of free creative specialists in the "Culture and Art" sector where competition for positions exceeds the average figure for the other cities by two times and is 6 and 2 people respectively.

In the methodology for determining the Creative Capital Index of the world capitals, leading in creative environment development, the "Government" sector does not include such indicator as "Support for budget sector industries" which is calculated for Russian cities. Experts included this indicator in the benchmarking of the creative capital for Russian cities, apparently due to the traditionally great importance given to providing employment and financing from state budget funds for science and education in the regions.

In "Government" and "Brand" sections New York is an undisputed leader in all the indicators, while the anti-leader for most of the indicators in these sections is Moscow.

Seoul became the only city in the study to show the negative dynamics of the creative sector in the city's GRP (the creative sector grew by $13 \%$ over the past five years against the overall growth of the creative economy by $22 \%$ ). The experts explain this fact by increased competition brought about by creative industries' development in the neighboring regions.

The findings of this study show that in the 21 st century creative sector is the key driving force for urbanized centers' development, increasing their economic efficiency and giving them a solid competitive edge.

\section{References:}

Analytical materials (2016). In search of new resources: the creative environment of Russian cities. Calvert Forum

Analytical materials (2014). The Creative Industries: potential of St. Petersburg and experience of other cities (Berlin, Moscow, London).Calvert Forum.

Creative Capital in Global Cities (2018). PWC publications.

Creative capital index (2017). Calvert 22 and PwC

Florida, R. (2005).Creative Class: People Who Change the Future. Moscow: Classic-XXI.

Galkina, N. (2018) Creative sector of national exports. Creative Industries. Kommersant, 31.01.

Landry, C. (2011). The Creative City. Moscow. Classic - XXI century.

Pine, I. B. J. \& Gilmort, J. H. (1999) The Experience Economy: Work is Theatre \& Every Business a Stage. Harvard Business Press. 
The UNESCO Creative Cities Network (2004).UNESCO

Third Creative Industries Report (2015). Development and Potential. Berlin

Paper submitted

Paper accepted for publishing

Paper published online
23 November 2019

23 January 2020

02 April 2020 